Arab World English Journal (AWEJ) Volume 12. Number2 June 2021

DOI: https://dx.doi.org/10.24093/awej/vol12no2.26

\title{
Service-learning in English as a Second Language Teacher Training Program: Exploring Pre- service Teachers' Authentic Learning Experiences
}

\author{
Fetylyana Nor Pazilah \\ Faculty of Education \\ Universiti Kebangsaan Malaysia, Malaysia \\ Corresponding Author: fetylyananor@gmail.com \\ Harwati Hashim \\ Faculty of Education \\ Universiti Kebangsaan Malaysia, Malaysia \\ Melor Md Yunus \\ Faculty of Education \\ Universiti Kebangsaan Malaysia, Malaysia
}

Received: 2/25/2021

Accepted: 6/18/2021

Published: 6/24/2021

\section{Abstract}

As the world we live in has become more digitalized, challenges are occurring left and right, especially in the education field. In gaining quality teachers, there is a need to train future educators to have the ability to adapt to the ever-changing technology and global changes. However, pre-service teachers often seem unprepared and unable to adapt to changes. Hence, implementing service-learning in the teacher training program is vital as it provides the opportunity to engage and experience 21 st-century real classroom lessons. Service-learning has also been proven to be an effective approach in training pre-service teachers. This paper aims to investigate the perceptions of pre-service teachers toward service-learning in terms of authentic learning experiences. It highlights how the implementation of service-learning approach in learning to teach writing in a second language context facilitates preservice teachers in terms of authentic experience. A qualitative method was conducted to investigate the authentic learning experiences among 54 pre-service teachers in a public university in Malaysia. Data were collected through open-ended questions. Based on this study, the findings showed that the preservice teachers could experience the real-life environment of teaching and learning and applying educational theories learned. They were also able to obtain hands-on experience in interacting with the students and marking their sample essays. It is hoped that future teachers and educational organizations can benefit from understanding the benefits of service-learning in teacher training programs. Future researchers could investigate the challenges of service-learning in teacher training programs.

Keywords: English as a second language, authentic learning experience, digital knowledge, pedagogical knowledge, pre-service teachers, teachers training, service-learning

Cite as: (2021). Service-learning in English as a Second Language Teacher Training Program: Exploring Pre-service Teachers' Authentic Learning Experiences. Arab World English Journal, 12 (2) 377-398.

DOI: https://dx.doi.org/10.24093/awej/vol12no2.26 


\section{Introduction}

Having quality education is a demand all over the world. It is one of the 17 Sustainable Development Goals stated by the United Nations to ensure inclusive and equitable quality education and promote a more lifelong opportunity for everyone. To achieve this goal, teachers play one of the most critical roles. As the world is continuously changing, and the students are becoming more digital natives, teachers need to be flexible in adapting to future global changes and the ever-changing technological wave. According to the World Economic Forum Education 4.0 Framework (2020), having technological skills is a must as we move deeper into the era of 4IR. This includes the content based on developing digital skills, including programming, digital responsibility, and the use of technology.

The Malaysia Education Blueprint 2015-2025 (Higher Education) highlighted that globalized online learning would be one of the primary educational shifts. Teachers are required to maximize the use of technology to ensure high-quality education (Ministry of Higher Education Malaysia, 2013). This actively demonstrates that; teachers will need to be capable of handling technology to ensure that lessons can be aligned with the current and future generations of digital natives and the era of 4IR.

Due to the constant demands from parents and students on quality education (Mitchell, Hirn \& Lewis, 2017), educators are facing incomparable challenges in adapting new teaching methods to adapt to current generation students who are digital natives (Hashim, 2018), and they need to keep up to the learners' interest (Samat, Hashim \& Yunus, 2019). Hence, being an effective teacher is crucial in this ever-changing era. Yazan (2019) stated that understanding all the problems and challenges one will face is crucial for future teachers. As education is becoming more and more significant in everyone's lives, teachers play a greater role in ensuring that all students can get equal opportunity and knowledge.

Having quality teachers in order to strive for quality education is giving significant responsibilities to teacher training programs. Training teachers require significant effort to ensure quality teachers. Yunus, Hashim, Ishak, and Mahamod (2010) highlighted that most pre-service teachers are still seem not ready to face challenges in a classroom despite innumerable ways and implementation conducted in training future teachers. A Malaysianbased study conducted by Goh and Matthews (2011) addressed that pre-service teachers often face difficulties and cannot respond to circumstances during practicum teaching. This is due to the lack of practice and the different situations that were given on campus-based learning.

Thus, the pre-service teachers must be given prior exposure even before going for practicum teaching. Implementing service-learning can ensure preparedness among preservice teachers, and it is vital to support the critical social values and educational practices among trainee teachers (Carrington, Mercer, Lyer \& Selva, 2015). Service-learning was primarily conducted by higher education and led by academics in the west (Bringle \& Hatcher, 1996, 2000; Butin, 2003) which then influenced other universities around the globe (Yusof, Tengku Ariffin, Awang-Hashim, Nording, \& Kaur, 2020). In Malaysia, the current blueprint included service-learning as a practical approach in enhancing teacher education at the tertiary level (Ministry of Education Malaysia (MoE), 2015). Service-learning should be 
implemented in a more structured and systematic manner into the academic program (Ministry of Education Malaysia (MoE), 2015). This is due to the potential that servicelearning can influence pre-service teachers' commitment, understanding of the pedagogy, and sensitivity towards students' differences (Ashton \& Arlington, 2019).

Service-learning is one of the most innovative teaching methodologies that allows service with academic study to strengthen communities (Scott \& Graham, 2015); plus, it is also a growing pedagogy implemented in higher institutions and teacher education (Mergler et al., 2017). Other than that, through the implementation of service-learning projects in teacher training programs, pre-service teachers will be able to engage in hands-on experience working with students and utilizing technologies in their lessons (Song, 2018). However, there is still a gap in discussing the effectiveness of service-learning in teachers' training programs, particularly in authentic experiences gained by pre-service teachers, which include exposure to the real-life environment of teaching and learning, hands-on experience in interacting with the students and, applying digital and pedagogical knowledge as well as theories in a real classroom environment.

Mastering all the skills in the English language is crucial for all English as a Second Language (ESL) teachers and learners. Teaching and learning the second language can be considered as a complicated process that can also contribute to feelings of fear and anxiousness (Toh \& Rahmat, 2021). Particularly in writing, ESL learners often find it challenging to master. Some of the challenges are poor grammar, lack of vocabulary, and even poor spelling (Moses \& Mohamad, 2019). It is pivotal that teachers should be well equipped with suitable teaching approaches and identify ways to motivate the students to ensure that the students can master the skill (Abrar, 2016). In order to effectively produce quality teachers, particularly ESL pre-service teachers, service-learning should be integrated into teacher training programs.

Implementing service-learning in the teacher training programs is more than suitable as studies have shown that service-learning can help both teachers and students engage in authentic dialogue, gain confidence and develop skills relevant to the targeted language (Bippus \& Eslami, 2013; Garver, Eslami \& Tong, 2018). It is crucial to note that servicelearning has been associated with countless benefits, such as increasing students' learning and providing authentic experience (Salam, Awang Iskandar, Ibrahim \& Farooq, 2019). This study can significantly provide ideas on how can service-learning be implemented in courses and offers the pre-service teachers' perceptions on its effectiveness particularly in an ESL context. The main purpose of this paper is to investigate the perceptions of pre-service teachers toward service-learning in terms of authentic experiences

The main objective of this study is to investigate Teaching English as a Second Language (TESL) pre-service teachers' perceptions towards service-learning approach in terms of authentic experience and highlights the question of how can service-learning approach in learning to teach writing in an ESL context facilitate pre-service teachers in terms of authentic experience. This study also discussed mainly on the framework Cone of Experience. Cone of Experience expresses characterizing learners realistically and observing their experience (Davis \& Summers, 2015). Edger Dale's Cone of Experience (Figure one) 
employs a positive influence on students and develops their leadership skills. Cone of Experience also explains the process of gaining experience from learning state to performing what they have learned.

\section{Literature Review \\ Cone of Experience}

The Cone of Experience was introduced in 1946 by Edgar Dale. The theory (shown in Figure 1) focuses on the progression of the experiences. The cone goes from concrete (bottom of the cone) to the most abstract (top of the cone) (Davis \& Summers, 2015). According to Davis and Summers, these levels are known for learners to be 'doing.' The middle cone is said to 'observe' the experience. The top two levels are different from the one at the bottom, where students do not interact directly with the phenomena such as demonstrations, field trips, and even learning in lecture halls (Davis \& Summers 2015). The further down one goes in the progress, the more information received. According to Masters (2013), the bottom level is where one would 'do the real thing' (p.4). Dale describes the value as 'direct, firsthand, experiences in which becomes the foundation of our learning' (as cited in Masters, 2013). Effective learning environments should be filled with rich and memorable experiences where students can see, hear, taste, touch, and try (Lee, 2016). The service-learning approach is known for its direct approach and hands-on experiences (Coffey \& Lavery, 2015), aligning with the framework.

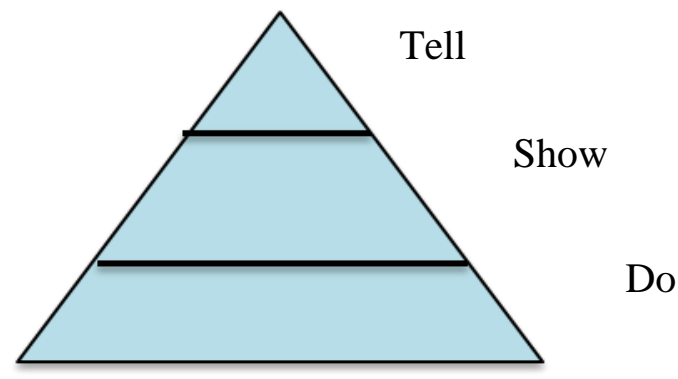

Figure 1. Dale's cone of experience by Davis and Summers (2015, P. 2)

Based on the Cone of Experience, it is significant that the pre-service teachers should be given all the knowledge necessary before venturing into a professional teaching profession. The Cone of Experience addresses the importance of learning and experiencing. The model also suggests a more enriching learning experience where the students would get the first-hand experience in conducting the activities themselves (Seels, 1997; Ogunleye, 2019). Service-learning approach is the perfect example for allowing students to apply what they have learned in lectures to a reallife environment. There are countless benefits that service-learning brings. Based on literature reviews, the researcher mapped out four main effectiveness of service-learning: authentic experiences, understanding of the course content, active participation, and engagement and problem-learning. The elements are then illustrated in a conceptual framework. Further explanations of the conceptual framework are detailed in the next section.

\section{Conceptual Framework}

A conceptual framework was modified to understand in-depth the effectiveness of service- 
learning and pre-service teachers' perceptions towards service-learning in teacher training programs. Based on reviews, a total of four main elements were mapped out which are authentic experiences (Grim, 2010; Soslau \& Yost, 2007), understanding of the course content (Bringle \& Hatcher, 1995; Bandy, 2016), active participation, and engagement (Sedlak, Doheny, Panthofer \& Anaya, 2003; Said, Ahmad \& Nor, 2019), and problem-based learning (Tawfik \& Trueman \& Lorz, 2014; Arnold, 2019). This study aims to investigate one of the elements in the framework, which is the perceptions of pre-service teachers on service-learning concerning authentic experiences. Despite countless studies conducted on service-learning, there are still very few done to study how the pre-service teachers perceived service-learning as part of teachers' training, particularly in authentic experiences gained. Figure two illustrates the conceptual framework.

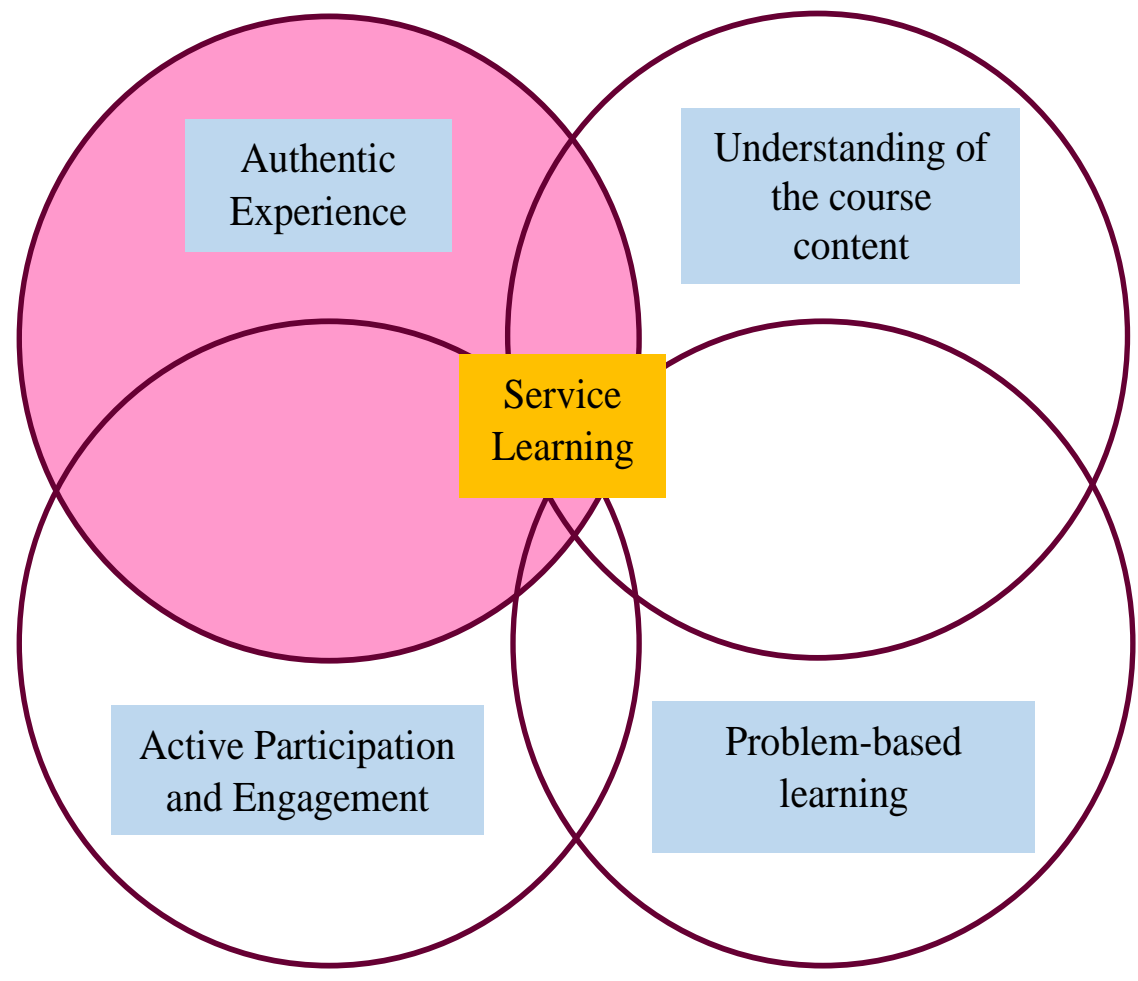

Figure 2: Service-Learning Conceptual Framework

Figure two shows the four elements studied and how it connects with service-learning. All the centralized elements are among the benefits gained from service-learning. Servicelearning is one of the most effective methods in exposing pre-service teachers to classroom challenges. Service-learning provides authentic experiences and practices in which students may not be able to get anywhere else (Coffey \& Lavery, 2015). Further explanation on service-learning and authentic experiences are further explained in the next section.

\section{Service-learning Approach as a Platform for Teachers' Training}

Billig, Root, and Jesse (2005) stated that service-learning could be broadly defined as a teaching strategy or method where the students can learn critical curricular objectives by providing service to a community and understand their needs, particularly in education. This 
practice is considered to be a versatile and diverse approach to implement in a broad range of educational settings, where educators aim for students to have meaningful and confrontational learning experiences (Mergler et al., 2017). Characteristically, the cycle in service-learning includes student planning, action, reflection, and celebration. In high-quality service-learning projects, students would have to voice out in determining activities, and the teachers will facilitate knowledge and skill acquisition (Billig et al., 2005). Pre-service teachers can contribute to the community and share their knowledge through service-learning programs. Traditional teaching methods, such as lecturing in large halls, are said to have lost students' interests and attention (Luo, Murray \& Crompton, 2020).

Service-learning has since developed a pedagogical approach in higher education, particularly colleges and universities and internationally, for more than a few decades (Bennet, Sunderland, Bartleet, \& Power, 2016). Service-learning connects theory and practice which allows students to practice what they have learnt and organize activities based on the community needs (Resch \& Schrittesser, 2019). Bennet et al. (2016) continued by stating that many institutions have struggled and almost achieved the impossible in instilling a sense of "service to the community" in courses to educate their students. Many programs require students to complete community service for specific hours to complete their graduation requirements. Often pre-service teachers would volunteer their time in schools to expand their learning and to gain teaching experience. In contrast to the act of volunteerism where citizens are called to serve others (Gaines-Hanks \& Grayman-Simpson, 2011), and service-learning is viewed as equal that includes preparation for experiential learning where pre-service teachers can make meaningful contributions to the society (Pratt \& Danyluk, 2017). Researchers believed that service-learning could result in a deeper understanding of concepts and heightened urgency to learn (Hullender, Hinck, Wood-Nartker, Burton, \& Bowlby, 2015). For example, Resch and Schrittesser (2021) suggest that service-learning promotes in depth understanding on the contents learnt and enhanced the sense of engagement. Due to the multiple positive effects that service-learning offers, researchers have also said that service-learning can reduce high-risk activities and social problems, such as drug abuse and anti-social problems (Mamati et al., 2018).

Training pre-service or beginner teachers is essential to ensure that they are ready to teach in the real world. Universities and colleges conduct numerous teachers' training programs to ensure students' full understanding and practices before teaching in real-life. Among the teachers' training programs are field trips, exhibitions, and even learning in lecture halls (Barnes, 2016). The service-learning approach has become one of the prominent presences among higher education institutions as it focuses on the impact of service-learning on the development of the college participants as contributing citizens of their community (Hildenbrand \& Schultz, 2015). Although service-learning has been proven to be a unique approach in exposing pre-service teachers to future challenges, there are very few researchers conducted in an ESL context. Swacha (2018) argues that there is still a gap that addresses ways to implement service-learning in ESL teacher training programs effectively. This can lead to difficulties for curriculum developers and teacher educators to figure out ways to successfully integrate service-learning in their courses. Chiva-Bartoll, Capella-Peris, and Salvador-García (2020) argued that service-learning-related works were also very technical rather than critical and reflective. It is pivotal that critical thinking should be implemented in 
service-learning and applied by the students as many university students tend to be lacking stated skill (Abrami, Bernard, Borokhovski, Waddington, Wade \& Persson, 2015). It is imperative that service-learning should be conducted to enhance the students' criticalthinking and problem-solving skills to ensure preparedness to teach in schools.

Other than that, previous studies conducted on service-learning implementation were also more towards one-off application and not for one whole semester. For example, servicelearning approach in a study by Shek, Yang, Ma, and Chai (2021) was conducted for 15 hours with secondary school students, and the services were provided by university students in Hong Kong. A study by Damons and Dunbar-Krige (2020) was conducted for three days during the April holidays. In this study, however, the service-learning was conducted for one whole semester with ESL pre-service teachers. Further explanation will be detailed in the methodology section.

\section{Authentic Experiences in Service-learning}

Authentic learning is referred to as life learning. Service-learning is a pedagogical approach that allows students to integrate the knowledge they have learned and apply it to serve the community (Winn, 2018). According to Hasnine, Ogata, Akcapinar, and Mouri (2019), authentic learning allows students to create concrete and useful materials for them to use and share. The importance of offering pre-service teachers' new ideas will challenge their critical thinking and engage them in solving problems (Ashton \& Arlington, 2019). The service-learning experience provides adventure and outdoor activities through a field trip experience (Tice \& Nelson, 2008). For example, a study by Tour (2017) found that teachers enjoy practicing meaningful and independent learning (as cited in Kearney \& Maher, 2019). Service-learning provides authentic relationships between communities, and we must implement it in higher institutions to expose the students to the possible challenges and complications (Clifford, 2017)

While this learning can be conducted in multiple ways, it is utterly significant for the pre-service teachers to understand the value of providing service and reflect in their attitudes and behavior and contribute to society through good citizenship and ethical practice (DeNobile, 2019). According to Hildenbrand and Schultz (2015), service-learning has become more relevant in teacher education as it provides an opportunity for pre-service teachers to participate and engage in life experiences rather than their own. In the current application of the principle, embedding service-learning can introduce active participation and exposure to real-world challenges (Lancaster \& Bain, 2019).

Prior exposure is significant as it can evolve pre-service teachers' soft skills. The knowledge and learning in service-learning will be able to connect students and teachers. Mitchell (2008) asserted that through providing their service, pre-service teachers would become active learners, bringing skills and information from community work and integrating theories learned and curriculum of the classroom to produce novel knowledge. By engaging the pre-service teachers in authentic learning outside their standard lecture classroom, pre-service teachers will be able to experience the repertoire of academic learning and develop sophisticated beliefs related to pedagogy for various contexts and diverse learners (Ryan \& Healy, 2009). Not only that, pre-service teachers can observe and endorse 
theories such as theories of communication, language, and learning and apply them in the real world, particularly in the classroom. Daniel and Mishra (2017) highlighted that servicelearning helps by situating pre-service teachers around real-life classroom challenges and benefits in receiving authentic experience.

In implementing service-learning, higher institutions can benefit from enhancing coursework with real applications and hands-on experience. The local community can also benefit in energizing young people of the community (Onal, Nadler, \& O'Loughlin, 2017). Real-life and authentic experiences can offer challenging tasks that promote much more active learning for pre-service teachers (Hero \& Lindfors, 2019). To be able to explore opportunities in an authentic experience, the pre-service teacher should be able to communicate effectively with their students (Whistance, 2018). In other words, participation in the authentic activity of the community can build relationships and knowledge, which can lead to learning (Cleland \& Durning, 2019)

Additionally, pre-service teachers need to have the opportunity to implement what they have learned through books and in-class activities with actual students. Service-learning allows pre-service teachers to apply their pedagogical and content knowledge with a community and understand their needs in learning (Pittman, Garfield \& Piper, 2020). In a service-learning environment, pre-service teachers can guide students in small groups in overcoming their complications and create a variety of solutions, encouraging and at the same time strengthening critical thinking (Siew, Amir \& Chong., 2015). The current wave of technology is forcing teachers to infuse their teaching with technology to attract millennials (Bowser et al., 2014; Hashim et al., 2016; Wan Azli, Shah \& Mohamad, 2018). Hence, the main objectives in teachers' education are to ensure that the pre-service teachers are well prepared to align with the digital progress (Rusli, Hashim, Yunus, Zakaria \& Norman, 2019)

Embedding service-learning in the coursework can undoubtedly improve pre-service teachers' soft skills such as problem-solving, leadership, and communication skills. Servicelearning also allows pre-service teachers to apply theory into practice and understand the complexities of real-life problems, thereby preparing them to be future leaders (Onal et al., 2017). Theories learned in lectures give extra knowledge and information on education in general, but they can also be applied in the classroom to manage the students and classroom environment (Lasker, 2019). A study conducted by Lenkauskaitė (2020) proved that service learning promotes real situations and circumstances that possibly can happen in a classroom situation. This can ensure pre-service teachers to be more open towards future challenges.

Besides, implementing service-learning can encourage pre-service teachers to integrate the content learned in lectures into real-life classrooms, such as videos, photovoice, quilting, and digital storytelling (Vecchio, Dhillon \& Ulmer, 2017). Implementing technology in teachers training program courses helped improve pre-service teachers' confidence in using technology (Kay, 2006). However, what is often lacking is applying their technical skills in a real classroom environment (Song, 2018). Thus, integrating service-learning projects in teachers training programs would just give a chance for pre-service teachers to take their skills to practice and have confidence in it. 


\section{Methodology \\ Design}

This study employed a qualitative method. A qualitative research strategy was conducted in an open-ended question to understand the pre-service teachers' perceptions towards service learning in terms of authentic experiences. The question was distributed as part of their final exam question. Interviews, as well as observation, were also conducted during the event. The data then analyzed using thematic analysis.

\section{Instrument}

This study employed an open-ended question, face-to-face interview, and observation. An open-ended questionnaire allows the participants to respond freely to the inquiry (Geer, 1988). It also allows the individuals to provide their opinions and respond spontaneously (Reja, Manfreda, Hlebec \& Vehovar, 2003). Both interviews and observation were conducted to understand the pre-service teachers' perspective on service-learning. Adhabi and Anozie (2017) suggest that interview is one of the most effective ways in conducting qualitative method research as it provides a more detailed analysis. The question was distributed to 56 undergraduate students at a public university in Malaysia.

\section{Participants}

The participants in this study were undergraduate students who were doing Bachelor in TESL program and were taking a course named Teaching of Writing in an ESL Context. A total of 56 students were involved in this study. To complete the coursework, the students had to conduct service teaching for a group of underprivileged students in Pahang, Malaysia. The duration of the program was for one semester in which they were required to go through the service-learning program and mentor the students. They were also required to teach and mentor the students of AMG. The participants for the interview were chosen voluntarily.

\section{Procedure of Data Analysis}

The data for this study were analyzed using thematic analysis. The analysis was performed using the four stages proposed by Cohen, Manion, and Morrison (2007), which generate natural units of meaning; labeling, categorizing, and ordering the natural units; constructing narratives; and interpretation. The data were later themed based on the participants' responses.

\section{Procedure of Data Collection}

In this study, a qualitative method was conducted. The participants were given an openended question to answer as part of their final exam question. Observation and interviews were also conducted to achieve in depth understanding of the service-learning concept. There are a few steps for the researcher to obtain the data. The steps are illustrated below. 


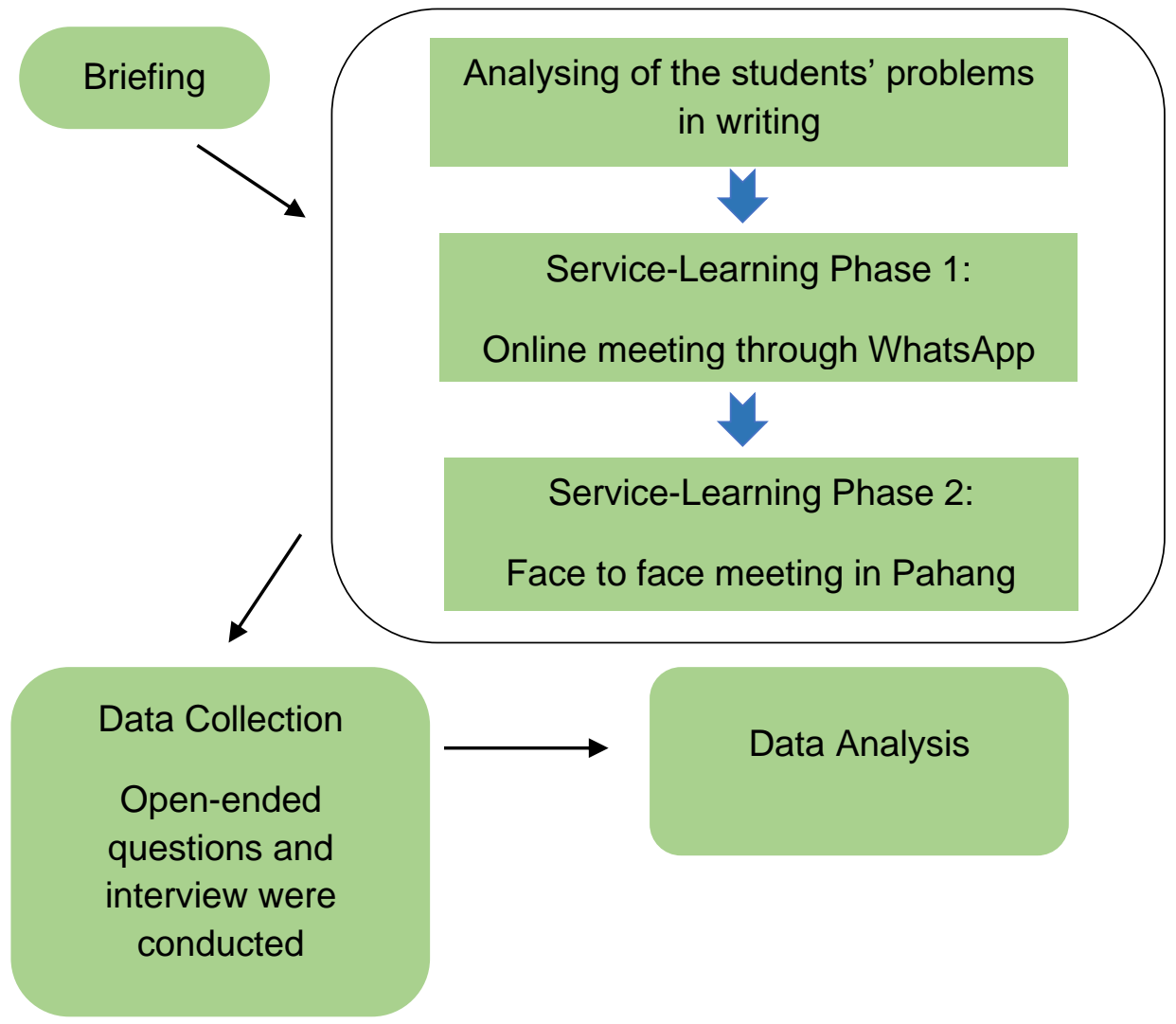

Figure 3: Data collection procedure

The service-learning method in this study was conducted throughout the semester and started at the beginning of the semester. The pre-service teachers were given a task to mentor underprivileged students in the state of Pahang, Malaysia. The pre-service teachers were taught and briefed on teaching pedagogy and the marking schemes before teaching the students. The students were divided into groups of two to four, and each group was given one teacher as their facilitator.

The pre-service teachers were given the students' essays to analyze and understand their problems in writing. Service-learning phase one began through a communication application, WhatsApp, where the pre-service teachers communicated with the students to recognize more on the students' complications in writing and their way of learning. The students were mainly poor to moderate proficiency students. The face-to-face meeting happened in phase two of service-learning. The pre-service teachers came up with suitable teaching methods to suit the students' learning styles and tackle their complications in English writing. The session was conducted for one whole day in Pahang. A qualitative research strategy was conducted in an open-ended question to understand the pre-service teachers' perceptions of service-learning in authentic experiences. The question was distributed as part of their final exam question.

\section{Findings}

The primary purpose of this study is to investigate the TESL pre-service teachers' perceptions towards service-learning in terms of authentic experiences. A total of 56 TESL 
pre-service teachers were involved in this study. The pre-service teachers were asked based on their perspectives on how can service-learning approach in learning to teach writing in an ESL context facilitates pre-service teachers in terms of authentic experiences. A fully qualitative method was conducted, and open-ended questionnaire were given to the pre-service teachers to explore their perceptions. Both interviews and observation were also conducted during the event. Table one presents the findings.

Table 1: TESL Pre-service teachers' perceptions towards service-learning in terms of authentic experiences

\begin{tabular}{|c|c|c|}
\hline Question & Themes & Exemplary Notes \\
\hline \multirow[t]{3}{*}{$\begin{array}{l}\text { How can service-learning } \\
\text { approach in learning to teach } \\
\text { writing in an ESL context } \\
\text { facilitate pre service teachers in } \\
\text { terms of authentic experiences }\end{array}$} & $\begin{array}{l}\text { Exposure to Real Life Environment } \\
\text { of Teaching and Learning }\end{array}$ & $\begin{array}{l}\text { Pre-service teachers are being } \\
\text { exposed to possible problems and } \\
\text { consequences that occur during } \\
\text { service-learning......(p4) } \\
\text { We were given the students' essay to } \\
\text { identify the student' strengths and } \\
\text { weaknesses and provide better } \\
\text { solutions to the students (P16) } \\
\text { We were required to develop our own } \\
\text { teaching materials...... (P8) } \\
\text { Service-learning provides authentic } \\
\text { experience in a way that it prepares } \\
\text { the teachers for the unexpected } \\
\text { students' behavior......(P32) }\end{array}$ \\
\hline & $\begin{array}{c}\text { Hands-on Experience in Interacting } \\
\text { with the Students }\end{array}$ & $\begin{array}{l}\text { I was able to use Facebook as a } \\
\text { medium to teach writing in } \\
\text { ESL...(P50) } \\
\text { Games such as Quizizz, Kahoot were } \\
\text { implemented in teaching to attract the } \\
\text { students' attention...... (P38) } \\
\text {...I was able to correct their essays. I } \\
\text { also gave them some English } \\
\text { exercises to be done... (P23) } \\
\text { The pre-service teachers had the } \\
\text { opportunity to use board games with } \\
\text { the students to attract their attention } \\
\text { and improve their grammar (P33) }\end{array}$ \\
\hline & $\begin{array}{l}\text { Applying Digital and Pedagogical } \\
\text { Knowledge and Theories in a Real } \\
\text { Classroom Environment }\end{array}$ & $\begin{array}{l}\text { I was able to use the theories that we } \\
\text { learned in class in real life......(P12) } \\
\text { Instagram is a very modern approach } \\
\text { and every student seems to have an } \\
\text { Instagram account.... (P9) }\end{array}$ \\
\hline
\end{tabular}

Note: $\mathrm{P}=$ Participants

As shown in Table one, the pre-service teachers were able to gain authentic experiences from service-learning. Service-learning provided exposure to real-life teaching and learning environment. The pre-service teachers managed to identify the students' strengths and 
weaknesses and provide solutions to cater to their learning styles. Service-learning also offered hands-on experience in interacting with the students. Conducting activities, teaching and even correcting the students' mistakes were among the experiences gained through service-learning. Other than that, service learning allows the pre-service teachers to apply the knowledge learned in lectures to a real classroom environment. The implementation of Instagram and Facebook were often used to suit the students' learning needs as they are more familiar with those applications. They were also able to apply the theories learned in real life. Further discussion is detailed in the next section.

\section{Discussion}

\section{Exposure to Real Life Environment of Teaching and Learning}

Based on the answers, it can be seen that service-learning provides numerous experiences, and one of it would be that it provides a real-life environment of teaching and learning towards pre-service teachers. A real-life environment is not a familiar atmosphere that preservice teachers can get anywhere, and it differs from what they might have expected. According to respondent four, she mentioned that they were able to experience how the teaching and learning process works and how to manage the classroom. It was explained in her comment that,

"Pre-service teachers are being exposed to possible problems and consequences that occur during service-learning. For example, pre-service teachers need to manage and conduct the activities for a certain period".

Challenges and complications often occur in a classroom, and a teacher should be able to control and manage the classroom. As stated by (Hero \& Lindfors, 2019), service-learning offers an authentic experience that provides challenging tasks and promotes active learning among pre-service teachers. Respondent 16 mentioned that they were able to identify their strengths and weaknesses in teaching.

"Through face to face meeting with the students, the teacher will be able to tell the students weaknesses and strengths as well as help them by giving solutions through discussion".

Participant 16 expressed that,

"We were given the students' essay to identify the students' strengths and weaknesses and provide better solutions for them."

During the teaching and learning process, the teachers can recognize their teaching technique as it may and may not be effective. Service-learning provides the chance to guide and overcome complications as well as develop critical thinking to ensure that the teaching can be helpful (Siew et al., 2015). Other than that, service-learning proposes real-life responsibilities that the students will face. Mitchell (2008) stated that service-learning helps to connect students and institutions by providing service, while instilling moral and social responsibilities among students. They will have to be responsible for teaching and ensure that it is valuable and practical at the same time, caters to all the students' needs. 
Participant eight detailed,

"We were required to develop our own teaching materials which connect to our creativity and at the same time cater to the students' needs to improve writing".

Through service-learning, students will also be able to learn how to manage a classroom. Service-learning has proven to develop skills and provide real-life experiences (Coffey \& Lavery, 2015). Managing a real-life classroom is not a situation or the environment that is common to see among tertiary-level students. Mock-teachings may have helped them in exposing possible challenges; however, it is nothing to be compared with the actual situation. During the impromptu interviews, the pre-service teachers often implied that it was difficult and challenging for them to handle the students as some are quite shy and introverts, as well as encouraging them to learn. Respondent 13 stated that service-learning assisted them in managing the classroom to ensure the students' attention and good behavior. In her comment, she noted that,

"Teachers will have to face inquiries as well as students' behavior. Teachers would have to deal with lazy and uncooperative students".

Respondent 32 explained that,

"Service-learning provides authentic experience in a way that it prepares the teachers for the unexpected students' behavior. So, this unexpected behavior will make the teachers more creative to tackle their students' attention and helps them to improve".

Participant 28 mentioned,

"It wasn't easy to handle the students despite we only get to mentor three to four of the students only. Some of them are very passive and some of them are very active.

We have to make sure that all students can achieve the objectives in learning".

Participant 24 said,

"Teachers really do have to be patient. It was not easy but I know it is better to hold the anger or frustrations than letting it go on students".

Being a teacher is essential to show moral values and the right attitude towards the students (DeNobile, 2019).

\section{Hands-on Experience in Interacting with the Students}

Having to experience for oneself is significantly different from learning in a lecture hall. The service-learning experience provides adventure and outdoor activities through a field trip experience (Tice \& Nelson, 2008). Not only that, the pre-service teachers were able to conduct the activities along with the students themselves and have a one-on-one consultation with them. The trainee teachers were given two to three students for them to monitor and conduct activities. From here, they were able to identify the students' weaknesses, strengths and their complications in ESL learning, especially in writing. The trainee teachers were also able to come up with suitable solutions for the students in learning as well as encouraging them to learn using various methods. Among the methods implemented would be learning through games, utilization of technology, and social media. In order to grab the millennials' attention, it is vital that teaching and learning session can match with the students' needs who are digital natives (Bowser et al., 2014; Hashim, Yunus, \& Embi, 2016; Wan Azli et al., 2018). 
Participant 50 expressed,

"I was able to use Facebook as a medium to teach writing in ESL. The students are millennials; hence it is vital to implement technology in teaching".

Participant 47 answered,

"The students are really into games so we taught of teaching them using board games".

Participant 38 mentioned,

"Games such as Quizizz, Kahoot were implemented in teaching to attract the students' attention. We also played board games".

Other than that, the trainee teachers can interact and communicate with the students before the event via WhatsApp. They were able to discuss with the students on the challenges faced in writing and understand the students' proficiency in ESL. It is crucial to ensure that teachers have decent communication skills. As asserted by Whistance (2018), for the pre-service teachers to explore opportunities in an authentic experience, the pre-service teacher should be able to communicate effectively with their students. Embedding servicelearning in the coursework can undoubtedly improve pre-service teachers' soft skills such as problem-solving skills, leadership skills, and communication skills. Service-learning also allows pre-service teachers to apply theory into practice and understand the complexities of real-life problems, thereby preparing them to be future leaders (Onal et al., 2017). Knowing the students and the early exposure towards the students' complications in learning can improve their communication skills. Participant 23 stated that they were able to communicate, understand the challenges faced by the students, and come up with an appropriate technique to teach them. She expressed that,

"We were able to communicate through a WhatsApp group and make discussion. I was able to correct their essays. I also gave them some English exercises to be done. When we finally met, I was introduced to the 'Burger' format'.

Participant 18 reflected in her comment that,

"Through service-learning, pre-service teachers are allowed to apply all theories that have been taught in the classroom".

Also, Participant 14 added in her comment that,

"Exposing novice teachers with more real-life experiences is important as they will have more experience in teaching and creating various types of learning strategies to deliver knowledge to the students. The experiences will make the teachers more creative and innovative".

Participant 46 said,

"Not only the students get to improve their writing and communication, but the preservice teachers were also able to improve their own writing and communication. This is because the teachers have to do some research on how to teach the students proper writing skills and grammar".

The pre-service teachers were also given real sample essays from the students for them to mark. Before the event, the students were instructed to write an essay. The essays were later collected and distributed to the teachers according to their group. The pre-service teachers were also able to experience marking and grading. Through marking real sample essays, the pre-service teachers were able to identify the students' strengths and weaknesses 
and develop suitable teaching methods for the students. They were also able to develop critical thinking skills in identifying the errors and the possible solutions to it. The importance of offering pre-service teachers with new ideas will challenge their critical thinking and engage them in activities to solve problems (Ashton \& Arlington, 2019). They also showed incredible creativity through handmade teaching materials in a game form to catch the students' attention in learning.

Participant 33 mentioned that,

"The pre-service teachers had the opportunity to use board games with the students to attract their attention and improve their grammar".

Participant 19 reflected in his comment that,

"The students were required to speak in English during teaching and learning session. Not only it can improve their English language skills, but it can also improve the preservice teachers' English language skills".

\section{Applying Digital and Pedagogical Knowledge and Theories in a Real Classroom Environment}

As teachers, having digital and pedagogical knowledge and understanding the theories is crucial. However, understanding and memorizing the pedagogy and the teaching theories differ significantly from applying in a classroom environment. Service-learning also allows pre-service teachers to apply theory into practice and understand the complexities of real-life problems, thereby preparing them to be future leaders (Onal et al., 2017). Theories learned in lectures not only give extra knowledge and information on education in general, but it also can be applied in classroom to manage the students and classroom environment (Lasker, 2019). Participant 12 noted that they were able to physically use the theories learned as well as the pedagogical knowledge when teaching and find it extremely useful.

"I was able to use the theories that we learned in class in real life. It is very interesting to see how the theories work".

Participant 10 stated in her comment that,

"Through service-learning, pre-service teachers can teach writing at the same time they can improve themselves and understand the teaching methods better".

Ryan and Healy (2009) explained that pre-service teachers could observe and endorse theories such as theories of communication, language, and learning and apply them in realworld contexts, particularly in the classroom. Other than that, using suitable teaching materials and methods would help the students to understand better. The pre-service teachers have developed and created a variety of teaching materials from handmade games to utilizing technology and social media. Participant nine stated that she uses Instagram to teach writing to the students as they are very familiar with social media. The students were also exposed to numerous ways of learning English.

She disclosed in her comment that,

"Instagram is a very modern approach and every student seems to have an Instagram account. They were able to describe better through scrolling pictures on Instagram".

Participant 13 mentioned,

"Using technology in class was really able to break the ice. My students are very 
passive and it was difficult to get them to participate, but when Instagram and Facebook were involved, they finally get to speak their opinions and participate".

Service-learning allows pre-service teachers to apply their pedagogical knowledge for different contexts and diverse students. Other than that, service-learning provide the opportunity to apply age-old theories in a real-life environment. Renowned education theories such as Behaviorism are commonly being used among teachers to increase the students' attention. During the event, the pre-service teachers were frequently being seen giving out extrinsic and intrinsic rewards such as chocolates and compliments to the students who improved and were able to answer the questions. Giving out rewards and compliments to the students helped them in getting out of their comfort zone.

Participant 12 stated that,

"Behaviorism is constantly used among pre-service teachers. Most pre-service teachers would bring gifts to the students who did their work".

Respondent 22 mentioned,

"Whenever the students did a good job, they will be given rewards. This encourages them to do better in the next session. It is important that teachers know a way to tackle the students' interest and what caught their attention".

Participant 51 said,

"The theory Behaviorism really helped. It is quite interesting to see students get really excited for rewards. At the same time, it motivates them to learn".

Learning and applying what one has learned is a totally different experience. Preservice teachers mentioned that they managed to implement theories and witnessed how the theories worked. Resch and Schrittesser (2019) expressed that service-learning stands out due to its uniqueness in allowing pre-service teachers to connect theory and practice by participating in community activities. It provides the authentic experiences in which the preservice teachers may not achieve through reading.

\section{Conclusion}

Above all, service-learning has been proven in this study to bring countless exposure and authentic experience to the pre-service teachers. It is pivotal that teacher training programs implement effective training approaches and strategies to ensure that the pre-service teachers can be well-equipped with the necessary skills and knowledge. This is due to the constant reoccurring problems such as unpreparedness and the inability to adapt to changes. Pre-service teachers are seemingly not ready to teach in the real world. Hence, proper training should be given to the pre-service teachers in order to curb these problems. Service-learning is one of the most effective approaches that can be implemented in teacher training programs. This study aims to investigate TESL pre-service teachers' perceptions towards service-learning in terms of authentic experiences.

Based on the findings, this study also suggests that service-learning is one of the most effective ways of training teachers before venturing into schools. Early exposure to the preservice teachers to possible outcomes and challenges in schools is crucial as they will not experience the unexpected in an indoor classroom environment. There were also able to enjoy more independent and meaningful learning. Service-learning provides authenticity in learning 
that cannot be achieved in a lecture hall. This study also believes that service-learning offers the opportunity of interacting with the students. Service-learning or often associates with education in action requires students to be active and participate in activities. Hands-on experience is crucial as having to conduct an activity leaves a longer trace in one memory. This study also found that service-learning allows students to apply what they have learned in class to a real-life environment. Learning and applying pedagogical knowledge and education theories to a real-life event differs significantly as applying in real life guarantees a better understanding of the context.

It is believed that future teachers and educational organizations can benefit from this in gaining and understanding the benefits and effects of service-learning in teachers' training programs. Service-learning is essential to be employed in the teacher training programs as it proved to be useful and bring numerous positive impacts to the pre-service teachers' attitudes and behaviors. Service-learning can also improve pre-service teachers' soft skills such as communication and leadership skill. Service-learning is crucial to be embedded in teacher training courses as part of the coursework. Future researchers can investigate the challenges and other benefits of service-learning in teachers' training programs.

Acknowledgement This research is funded by Universiti Kebangsaan Malaysia (UKM) under research grant no. GG-2020-027 and GG-2021-003.

\begin{abstract}
About the Authors:
Fetylyana Nor Pazilah is a postgraduate student at the Faculty of Education, Universiti Kebangsaan Malaysia (UKM). She is currently pursuing her doctorate (PhD) in TESL. Her fields of interest are pre-service teachers' education, technology in education and gamification. ORCid ID: https://orcid.org/0000-0003-1460-4991
\end{abstract}

Harwati Hashim, $\mathrm{PhD}$, is a senior lecturer at the Centre for Innovation in Teaching and Learning, Faculty of Education, Universiti Kebangsaan Malaysia (UKM). She is an educational technology enthusiast and an m-learning practitioner. Her areas of concentration are TESL, mobile learning, Mobile-assisted Language Learning (MALL), technology acceptance as well as innovative pedagogy and the use of technology in teaching English as a Second Language (ESL). ORCid ID: https://orcid.org/0000-0002-8817-427X

Melor Md Yunus is an Associate Professor and currently serves as the Deputy Dean of Research and Innovation at the Faculty of Education, Universiti Kebangsaan Malaysia. She obtained her doctorate in TESOL from the University of Bristol, United Kingdom. She is best known for establishing the integration of ICT in teaching and learning besides having the enthusiasm in language education and innovation as well as TESL fields.

ORCid ID: https://orcid.org/0000-0001-7504-7143

\title{
References
}

Abrami, P. C., Bernard, R. M., Borokhovski, E., Waddington, D. I., Wade, C. A., \& Persson, T. (2015). Strategies for teaching students to think critically: A meta-analysis. Review of Educational Research, 85(2), 275-314.

Abrar, M. (2016). Teaching English problems: An analysis of EFL primary school teachers in 
Kuala Tungkal. In The 16th Indonesian Scholars International Convention (pp. 94101).

Adhabi, E., \& Anozie, C. B. (2017). Literature review for the type of interview in qualitative research. International Journal of Education, 9(3), 86-97.

Arnold, M. (2019, June). Problem-based Learning in Higher Education Service Learning: Implications for Theory-Practice-Transfer. In Exploring new fields through the scholarship of teaching and learning. Proceedings of 3rd EuroSoTL Conference (pp. 603-613).

Ashton, J. R., \& Arlington, H. (2019). My Fears Were Irrational: Transforming Conceptions of Disability in Teacher Education through Service Learning. International Journal of Whole Schooling, 15(1), 50-81.

Barnes, M. E. (2016). The student as teacher educator in service-learning. Journal of Experiential Education, 39(3), 238-253. https://doi.org/10.1177/1053825916643831

Bennett, D., Sunderland, N., Bartleet, B. L., \& Power, A. (2016). Implementing and sustaining higher education service-learning initiatives: Revisiting Young et al.'s organizational tactics. Journal of Experiential Education, 39(2), 145-163.

Billig, S., Root, S., \& Jesse, D. (2005). Learning on High School Students' Civic. May. School $K$-12. 4. https://digitalcommons.unomaha.edu/slcek12/4

Bippus, S., \& Eslami, I. (2013). Adult ESOL students and service learning: Voices, experiences, and perspectives. Language Teacher Research, 4, 587-597. doi:10.1002/tesj.89

Bowser, A. et al., (2014). Gamifying citizen science: A study of two user groups. Proceedings of the ACM Conference on Computer Supported Cooperative Work, CSCW, February, 137-140. https://doi.org/10.1145/2556420.2556502

Bringle, R. G., \& Hatcher, J. A. (1996). Implementing service learning in higher education. The Journal of Higher Education, 67(2), 221-239.

Bringle, R. G., \& Hatcher, J. A. (2000). Institutionalization of service learning in higher education. The journal of higher education, 71(3), 273-290.

Butin, D. (2003). Of what use is it? Multiple conceptualizations of service learning within education. Teachers college record, 105(9), 1674-1692.

Carrington, S., Mercer, K. L., Iyer, R., \& Selva, G. (2015). The impact of transformative learning in a critical service-learning program on teacher development: Building a foundation for inclusive teaching. Reflective Practice, 16(1), 61-72.

Chiva-Bartoll, O., Capella-Peris, C., \& Salvador-García, C. (2020). Service-learning in physical education teacher education: Towards a critical and inclusive perspective. Journal of Education for Teaching, 46(3), 395-407.

Cleland, J., \& Durning, S. J. (2019). Education and service: how theories can help in understanding tensions. Medical Education, 53(1), 42-55. https://doi.org/10.1111/medu.13738

Clifford, J. (2017). Talking about service-learning: Product or process? Reciprocity or solidarity? Journal of Higher Education Outreach and Engagement, 21(4), 7-20.

Coffey, A., \& Lavery, S. (2015). Service-learning: A valuable means of preparing pre-service teachers for a teaching practicum. Australian Journal of Teacher Education, 40(7), 86101. https://doi.org/10.14221/ajte.2015v40n7.7

Cohen, L., Manion, L., \& Morrison, K. (2007). Research Methods in Education. London and 
New York: Routledge

Daniel, K. L., \& Mishra, C. (2017). Student outcomes from participating in an international STEM service-learning course. SAGE Open, $7(1)$. https://doi.org/10.1177/2158244017697155

Damons, V., \& Dunbar-Krige, H. (2020). The Use of Reflection in a Service-Learning Project in a Post-Graduate Programme. Journal of Service-Learning in Higher Education, 11, 21-40.

Davis, B., \& Summers, M. (2015, August). Applying Dale's Cone of Experience to increase learning and retention: A study of student learning in a foundational leadership course. In Engineering Leaders Conference 2014 on Engineering Education (Vol. 2015, No. 4, p. 6). Hamad bin Khalifa University Press (HBKU Press).

DeNobile, J. (2019). Values Education: What, How, Why and What Next? Tạp Chí Nghiên Cứu Dân Tộc, 8(1), 30-33. https://doi.org/10.25073/0866-773x/258

Gaines-Hanks, N., \& Grayman-Simpson, N. (2011). Intercultural Tensions within International Service-Learning. Exploring Cultural Dynamics and Tensions Within ServiceLearning, 323.

Garver, R. A., Eslami, Z. R., \& Tong, F. (2018). I believe I can: Service-Learning to raise preservice teacher's efficacy with English Learners. The Reading Matrix: An International Online Journal, 18(2), 23-37.

Geer, J. G. (1988). What do open-ended questions measure? Public Opinion Quarterly, 52(3), 365-367.

Goh, P. S., \& Matthews, B. (2011). Listening to the Concerns of Student Teachers in Malaysia During Teaching Practice. Australian Journal of Teacher Education, 36(3). https://doi.org/10.14221/ajte.2011v36n3.2

Grim, F. (2010). Giving authentic opportunities to second language learners: A look at a French service-learning project. Foreign Language Annals, 43(4), 605-623.

Hashim, H. (2018). Application of technology in the digital era education. International Journal of Research in Counseling and Education, 2(1), 1-5.

Hashim, H., Yunus, M. M., \& Embi, M. A. (2016). Pre-University English as Second Language (ESL) Learners' Attitude towards Mobile Learning. Creative Education, 07(08), 11471153. https://doi.org/10.4236/ce.2016.78119

Hasnine, M. N., Ogata, H., Akçapınar, G., Mouri, K., \& Uosaki, N. (2019). Learning analytics to share and reuse authentic learning experiences in a seamless learning environment. In Companion Proceedings of the 9th International Conference on Learning Analytics and Knowledge (LAK'19) (pp. 398-407). Society for Learning Analytics Research (SoLAR).

Hero, L. M., \& Lindfors, E. (2019). Students' learning experience in a multidisciplinary innovation project. Education and Training, 61(4), 500-522. https://doi.org/10.1108/ET-06-2018-0138

Hildenbrand, S. M., \& Schultz, S. M. (2015). Implementing Service Learning in Pre-Service Teacher Coursework. Journal of Experiential Education, 38(3), 262-279. https://doi.org/10.1177/1053825915571748

Hullender, R., Hinck, S., Wood-Nartker, J., Burton, T., \& Bowlby, S. (2015). Evidences of Transformative Learning in Service-Learning Reflections. Journal of the Scholarship of Teaching and Learning, 15(4), 58-82. https://doi.org/10.14434/josotl.v15i4.13432

Kay, R. H. (2006). Evaluating strategies used to incorporate technology into preservice 
education: A review of the literature. Journal of Research on Technology in Education, 38(4), 383-408. https://doi.org/10.1080/15391523.2006.10782466

Kearney, M., \& Maher, D. (2019). Mobile learning in pre-service teacher education: Examining the use of professional learning networks. Australasian Journal of Educational Technology, 35(1), 135-148. https://doi.org/10.14742/ajet.4073

Lancaster, J., \& Bain, A. (2019). Designing university courses to improve pre-service teachers' pedagogical content knowledge of evidence-based inclusive practice. Australian Journal of Teacher Education, 44(2). https://doi.org/10.14221/ajte.2018v44n2.4

Lasker, G. A. (2019). Connecting Systems Thinking and Service Learning in the Chemistry Classroom. Journal of Chemical Education, 96(12), 2710-2714. https://doi.org/10.1021/acs.jchemed.9b00344

Lee, L. (2016). Autonomous learning through task-based instruction in fully online language courses. Language Learning \& Technology, 20(2), 81-97.

Lenkauskaitè, J. (2020). Service-Learning in Problem Solving in the Community: Pre-Service Teachers' Reflection on their Experience. Social Welfare: Interdisciplinary Approach, $1(10), 67-81$.

Luo, T., Murray, A., \& Crompton, H. (2020). International Review of Research in Open and Distributed Learning Designing Authentic Learning Activities to Train Pre-Service Teachers About Teaching Online Designing Authentic Learning Activities to Train PreService Teachers About Teaching Online. International Review of Research in Open and Distributed Learning, 18(7), 141-157. https://doi.org/https://doi.org/10.19173/irrodl.v18i7.3037

Ministry of Education Malaysia (MoE). (2015). Malaysia Education Blueprint 2015-2025 (Higher

Education). Ministry of Education Malaysia, 2025, 40.

Mamati, M. et al., (2018). Volunteering among students of introduction to management, UKM. International Journal of Civil Engineering and Technology, 9(7), 448-456.

Masters, K. (2013). Edgar Dale's Pyramid of Learning in medical education: A literature review. Medical Teacher, 35(11), e1584-e1593. https://doi.org/10.3109/0142159X.2013.800636

Mergler, A. et al., (2017). Exploring the value of service-learning on preservice teachers. Australian Journal of Teacher Education (Online), 42(6), 69-80.

Ministry of Higher Education Malaysia. (2013). Malaysia Education Blueprint 2013 - 2025. Education, 27(1), 1-268. http://linkinghub.elsevier.com/retrieve/pii/S0742051X10001435

Mitchell, B. S., Hirn, R. G., \& Lewis, T. J. (2017). Enhancing effective classroom management in schools: Structures for changing teacher behavior. Teacher Education and Special Education, 40(2), 140-153. https://doi.org/10.1177/0888406417700961

Mitchell, T. (2008). Traditional vs Critical Service Learning. Michigan Journal of Community Service Learning, 50-65.

Moses, R. N., \& Mohamad, M. (2019). Challenges Faced by Students and Teachers on Writing Skills in ESL Contexts: A Literature Review. Creative Education, 10(13), 3385-3391. https://doi.org/10.4236/ce.2019.1013260

Ogunleye, B. O. (2019). Effects of concrete-representational-abstract instructional strategy on chemistry performance of students with mathematics learning difficulties in Ogun State, Nigeria. KIU Journal of Education, 14(2), 135-151. 
Onal, S., Nadler, J., \& O'Loughlin, M. (2017). Applying Theory to Real-World Problems: Integrating Service-Learning into the Industrial Engineering Capstone Design Course. International Journal for Service Learning in Engineering, Humanitarian Engineering and Social Entrepreneurship, 12(2), 57-80. https://doi.org/10.24908/ijsle.v12i2.6659

Pittman, R. T., Garfield, T., \& Piper, R. E. (2020). Increasing the Literacy Knowledge of Teacher Candidates: Why Service-Learning Matters. Collaborations: A Journal of Community-Based Research and Practice, 3(1): 7, 1-11. https://doi.org/10.33596/coll.66

Pratt, Y. P., \& Danyluk, P. J. (2017). Learning what schooling left out: Making an indigenous case for critical service-learning and reconciliatory pedagogy within teacher education. Canadian Journal of Education, 40(1), 1-29.

Reja, U., Manfreda, K. L., Hlebec, V., \& Vehovar, V. (2003). Open-ended vs. close-ended questions in web questionnaires. Developments in applied statistics, 19(1), 159-177.

Resch, K., \& Schrittesser, I. (2021). Using the Service-Learning approach to bridge the gap between theory and practice in teacher education. International Journal of Inclusive Education, 1-15.

Rusli, R., Hashim, H., Yunus, M. M., Zakaria, N. Y. K., \& Norman, H. (2019). Leveraging the use of social media in teaching writing: A qualitative investigation among ESL preservice teachers. International Journal of Interactive Mobile Technologies, 13(11), 8594. https://doi.org/10.3991/ijim.v13i11.10910

Ryan, M., \& Healy, A. (2009). It's not all about school: Ways of disrupting pre-service teachers' perceptions of pedagogy and communication. Teaching and Teacher Education, 25(3), 424-429. https://doi.org/10.1016/j.tate.2008.11.010

Said, H., Ahmad, I., \& Nor, F. M. (2019). Exploring Outcomes of Service-Learning Participantion: Evidence from Pakistan. Malaysian Journal of Learning and Instruction, 16(2), 125-154.

Salam, M., Awang Iskandar, D. N., Ibrahim, D. H. A., \& Farooq, M. S. (2019). Service learning in higher education: a systematic literature review. Asia Pacific Education Review, 20(4), 573-593. https://doi.org/10.1007/s12564-019-09580-6

Samat, N. A. A., Hashim, H., \& Yunus, M. M. (2019). Live Streaming: A New Platform for ESL Learning. Creative Education, 10(12), 2899-2906. https://doi.org/10.4236/ce.2019.1012215

Scott, K. E., \& Graham, J. A. (2015). Service-Learning: Implications for Empathy and Community Engagement in Elementary School Children. Journal of Experiential Education, 38(4), 354-372. https://doi.org/10.1177/1053825915592889

Seels, B. (1997). The Relationship of Media and ISD Theory: The Unrealized Promise of Dale's Cone of Experience.

Sedlak, C. A., Doheny, M. O., Panthofer, N., \& Anaya, E. (2003). Critical thinking in students' service-learning experiences. College Teaching, 51(3), 99-104.

Shek, D. T. L., Yang, Z., Ma, C. M. S., \& Chai, C. W. Y. (2021). Subjective outcome evaluation of service-learning by the service recipients: Scale development, normative profiles and predictors. Child Indicators Research, 14(1), 411-434.

Siew, N. M., Amir, N., \& Chong, C. L. (2015). The perceptions of pre-service and in-service teachers regarding a project-based STEM approach to teaching science. SpringerPlus, 4(1), 1-20. https://doi.org/10.1186/2193-1801-4-8

Song, L. (2018). Improving Pre-Service Teachers' Self-Efficacy on Technology Integration 
Through Service Learning. The Canadian Journal of Action Research, 19(1), 22-32.

Soslau, E. G., \& Yost, D. S. (2007). Urban service-learning: An authentic teaching strategy to deliver a standards-driven curriculum. Journal of Experiential Education, 30(1), 36-53.

Swacha, K. Y. (2018). Service-learning in the second language writing classroom: Future directions for research. TESOL Journal, 9(2), 278-298.

Tawfik, A., Trueman, R. J., \& Lorz, M. M. (2014). Engaging non-scientists in STEM through problem-based learning and service learning. Interdisciplinary Journal of ProblemBased Learning, 8(2), 4.

Tice, K. C., \& Nelson, L. P. (2019). Towards Understanding When Service-Learning Fosters Efficacy Beliefs of Preservice Teachers. Educating Teachers and Tomorrow's Students through Service-Learning Pedagogy, 105-120.

Toh, C. W., \& Rahmat, N. H. (2021). An Investigative Study on the Types and Causes of Esl Writing Anxiety: a Case Study of Learners From a Chinese Independent Middle School. European Journal of English Language Teaching, 6(3), 19-36. https://doi.org/10.46827/ejel.v6i3.3553

Vecchio, L., Dhillon, K. K., \& Ulmer, J. B. (2017). Visual methodologies for research with refugee youth. Intercultural Education, 28(2), 131-142.

Wan Azli, W. U. A., Shah, P. M., \& Mohamad, M. (2018). Perception on the Usage of Mobile Assisted Language Learning (MALL) in English as a Second Language (ESL) Learning among Vocational College Students. Creative Education, 09(01), 84-98. https://doi.org/10.4236/ce.2018.91008

Whistance, T. (2018). Engaging British Sign Language/English interpreting students through the use of situated learning. Student Engagement in Higher Education Journal, 2(2), $149-160$.

Winn, J. (2003). Avoiding death by PowerPoint. Journal of Professional Issues in Engineering Education and Practice, 129(3), 115-118.

World Economic Forum. (2020). Schools of the future: Defining new models of education for the fourth industrial revolution. World Economic Forum Reports 2020. www.weforum.org

Yazan, B. (2019). Toward identity-oriented teacher education: Critical autoethnographic narrative. TESOL Journal, 10(1), 1-15. https://doi.org/10.1002/tesj.388

Yunus, M. M., Hashim, H., Ishak, N. M., \& Mahamod, Z. (2010). Understanding TESL preservice teacher's teaching experiences and challenges via post-practicum reflection forms. Procedia - Social and Behavioral Sciences, 9, 722-728. https://doi.org/10.1016/j.sbspro.2010.12.224

Yusof, N., Tengku Ariffin, T. F., Awang-Hashim, R., Nording, H., \& Kaur, A. (2020). Challenges of Service-learning practices: Student and faculty perspectives from Malaysia. Malaysian Journal of Learning and Instruction, 17(2), 279-309 